\title{
Phenolic Content, DPPH Radical Scavenging, and Tyrosinase Inhibitory Activities of Ecklonia cava Extracted with the Ultrasonic Wave Method
}

\author{
So Jung Kim¹, Donggiun Kim², Jongbum Park ${ }^{2}$ and Taek-Kyun Lee $^{3}$ * \\ ${ }^{1}$ Kyeongbuk Institute for Marine Bio-Industry, Wooljin 767-813, Korea \\ ${ }^{2}$ Department of Biological Science, Silla University, Busan 617-736, Korea \\ ${ }^{3}$ Sauth Sea Environment Research Department, Korea Institute of Ocean Science and Technology, Geoje 656-830, Korea
}

Received June 19, 2013 /Revised July 10, 2013 /Accepted July 12, 2013

\begin{abstract}
The applicability of the ultrasonic wave method to the extraction of useful components from seaweeds was investigated. Extracts from freeze-dried Eckonia cava powder were prepared with hot water $\left(65^{\circ} \mathrm{C}\right)$, water $\left(24^{\circ} \mathrm{C}\right), 50 \%$ ethanol, and $100 \%$ ethanol, and ultrasonic extraction was also performed. The content of phenolic compounds and the 1,1-diphenyl-2-picrylhydrazyl (DPPH) radical scavenging activity and tyrosinase inhibitory activity of the extracts were analyzed, and differences in the data obtained by the ultrasonic extraction and the traditional extraction methods were compared. The phenolic content in the E. cava extract by ultrasonic extraction $(142.80 \mathrm{mg} / \mathrm{g})$ was approximately 14 times higher than the phenolic content in the hot water extract $(10.03 \mathrm{mg} / \mathrm{g})$. The DPPH radical scavenging and the tyrosinase inhibitory activities of the ultrasonic extract were approximately 4 times and 14 times higher than the hot water extracts, respectively. The correlation between the phenolic content and the DPPH radical scavenging activity (R2=99.47) and between the phenolic content and the tyrosinase inhibitory activity ( $\mathrm{R} 2=99.99)$ was very high. These results indicate that ultrasonic extraction is more suitable than traditional extraction for the extraction of useful components from $E$. cava.
\end{abstract}

Key words : Ultrasonic extraction, Ecklonia cava, phenolics, DPPH assay, tyrosinase inhibitory activity

\section{서 론}

해양에는 지구상 모든 생물종의 약 $80 \%$ 가 서식하고 있고, 막대한 자원량이 보고되고 있어, 미래 육상생물자원을 대체 할 중요한 식량자원으로 주목받고 있다[15]. 또한 해양의 환 경은 고염, 고압 및 저산소 등 육상과 매우 다르기 때문에, 해양에 서식하고 있는 해양생물은 물질대사 결과 생성될 수 있는 세포 내 구성성분이 육상생물과 크게 다를 것으로 예견 되고 있다[14, 23]. 따라서 해양생물로부터 기능성물질을 탐색 하고, 이를 식품 및 식품첨가제로 이용하고자 하는 연구가 활 발하게 수행되고 있으며, 시장성은 급속하게 증가하고 있는 추세이다[6].

전세계적으로 약 6,000 종의 해조류가 알려져 있으며[4], 약 150 여종의 해조류가 식품으로 이용되고 있다[20]. 해조류는 고대부터 식품, 사료 및 비료 뿐만 아니라 의약품의 원료로써 사용되어 왔으며, 최근에 해조류의 항산화 및 항박테리아 활

\footnotetext{
*Corresponding author

Tel : +82-55-639-8530, Fax : +82-55-639-8509

E-mail : tklee@kiost.ac

This is an Open-Access article distributed under the terms of the Creative Commons Attribution Non-Commercial License (http://creativecommons.org/licenses/by-nc/3.0) which permits unrestricted non-commercial use, distribution, and reproduction in any medium, provided the original work is properly cited
}

성이 알려지면서 식품과 화장품을 위한 원료로 주목받고 있다 [5]. 특히 감태(Ecklonia cava)는 페놀성 화합물인 phlorotannin 의 함량이 높고, 항산화, 항암 및 항고혈압 등의 기능이 밝혀지 면서 새로운 기능성소재로써의 가능성이 알려지고 있다 $[1,10$, 11].

식물로부터 유용성분을 획득하기 위한 다양한 연구가 수행 되고 있으며, 열수추출법, Soxhlet법, 고온 용매 추출법 및 기 계적 압착법 등의 전통적인 방법이 주로 사용되고 있다[3, 13]. 전통적인 추출법은 수율이 낮고, 열에 의해 변성될 수 있으며, 추출용매의 소모량이 많아 비용이 높아진다는 단점을 가지고 있다[28]. 이에 따라 최근에는 초임계 유제법, 초고압 처리법, 막 분리법, 초음파 처리법 및 마이크로파 처리법 등이 이용되 고 있으며, 이 중 초음파 추출법은 천연물 산업에서 효율적으 로 활용되고 있다[17, 27]. 또한 초음파 추출법은 일반 실험실 에서 흔히 볼 수 있는 초음파 세척기로도 충분히 사용이 가능 하기 때문에, 해조류 추출을 위한 활용도가 높을 것으로 예측 되고 있다[25].

우리는 이전 연구에서[11] 우리나라 거제도 및 제주도에서 30 여종의 해조류를 채집하고, $50 \%$ 에탄올 추출물의 페놀성 화합물 함량 및 생물학적 활성 분석을 수행한 바 있다. 분석된 30 종의 해조류 중 감태 추출물의 페놀성 화합물 함량, 항산화 활성 및 tyrosinase 저해 활성이 가장 높았으며, 특히 tyrosinase 저해 활성은 합성항산화제인 butylated hydrox- 
ytoluene보다 더 높아 천연 항산화 물질로써의 개발가능성을 제기하였다[11]. 이 연구에서는 초음파를 사용하여 감태로부 터 추출물을 얻고, 페놀성 화합물 함량, DPPH 라디칼 소거활 성 및 tyrosinase 저해 활성을 분석하고, 이를 일반적인 물 추 출물 및 에탄올 추출물과 비교하여, 해조류 유래 기능성 물질 추출에서의 초음파 추출법 활용가능성을 분석하고자 하였다.

\section{재료 및 방법}

\section{실험재료 및 추출}

실험재료인 감태(Ecklonia cava)는 울릉도에서 스킨스쿠버 를 이용하여 채집하였고, 한국 동해 연안 해조류 도감(국립수 산과학원)을 참고로 하여 동정하였다. 채집된 감태는 흐르는 물로 여러 번 씻어 염분을 제거한 뒤 동결건조기(일신랩, PVTYFD 10A, Korea)를 이용하여 건조 $\left(<-40^{\circ} \mathrm{C}, 2 \sim 3\right.$ 일)하였 다. 건조된 시료는 분쇄기(Lab. Blender, 51BL30, USA)를 이용 하여 분말화한 후, 초음파 추출과 용매 추출에 사용하였다. 초음파 저온 추출은 초음파 분산기(Sonics VC750, USA)를 사용하여 수행하였다. 동결건조된 감태 $600 \mathrm{~g}$ 에 10 배 $(\mathrm{w} / \mathrm{v})$ 의 정제수를 첨가하고, $40^{\circ} \mathrm{C}$ 에서 12 시간 추출한 후, $40 \mathrm{kHz}$ 에서 30 분간 초음파 추출을 병행하는 방법을 사용하였다. 추출용액 을 원심분리 $(5,000 \mathrm{rpm}, 5 \mathrm{~min})$ 한 후 상등액을 분리하였다. 물 및 에탄올 추출을 위해서 감태분말 $(5 \mathrm{~g})$ 에 $65^{\circ} \mathrm{C}$ 및 $24^{\circ} \mathrm{C}$ 물과 $50 \%$ 및 $100 \%$ 에탄올을 40 배 $(\mathrm{w} / \mathrm{v})$ 첨가하고, 12 시간 동안 $150 \mathrm{rpm}$ 에서 교반시킨 후, 원심분리기(Sorvall, USA)를 이용하여 상등액을 분리하였다 $(5,000 \mathrm{rpm}, 5 \mathrm{~min})$. 분리된 추 출액은 vacuum evaporator에서 건조하였고, 일정한 양을 각 각의 추출용매에 녹여 페놀성화합물 함량과 항산화 및 tyrosinase 저해 활성 분석에 사용하였다.

\section{페놀성 화합물 정량}

초음파 및 일반 추출법에 의해 추출된 각 추출물의 페놀성 화합물의 함량을 분석하였다. 시료 $0.5 \mathrm{ml}$ 와 $\mathrm{EtOH} 0.5 \mathrm{ml}$ 첨가 한 후 Folin-Ciocalteu 시약 $0.5 \mathrm{ml}, 1 \mathrm{ml}$ 의 $7.5 \% \mathrm{Na}_{2} \mathrm{CO}_{3}$ 를 첨가하고, 증류수로 최종 $10 \mathrm{ml}$ 를 맞추었다. $60^{\circ} \mathrm{C}$ 배양기에서 20 분간 발색시킨 후 $765 \mathrm{~nm}$ 파장에서 흡광도를 측정하였다. 대조구로서는 $50 \%$ 에탄올을 사용하였고, gallic acid를 사용하 여 구한 검량 곡선으로부터 시료 중의 페놀성 화합물 함량을 계산하였다.

\section{$\mathrm{DPPH}$ 라디칼 소거활성}

$\mathrm{DPPH}$ (1,1-diphenyl-2-picrylhydrazyl) 측정은 $\mathrm{Lu}$ 와 $\mathrm{Foo}$ 의 방법[19]에 따라 실시하였다. 시료 $0.2 \mathrm{ml}$ 에 $0.1 \mathrm{ml}$ 의 DPPH $(16 \mathrm{mg} / 100 \mathrm{ml} \mathrm{EtOH})$ 용액을 첨가하고 10 분간 상온에서 반응 시킨 후, $517 \mathrm{~nm}$ 에서 흡광도를 측정하였다. 시료를 첨가하지 않은 대조군과 비교하여 유리 래디칼 소거 활성을 백분율(\%)
로 나타내었다. 계산식은 아래와 같다.

Inhibition $(\%)=\left[\left(\mathrm{A}_{0}-\mathrm{A}_{1}\right) / \mathrm{A}_{0}\right] \times 100$

$\left(\mathrm{A}_{0}=\right.$ 대조군 흡광도 $\mathrm{A}_{1}=$ 실험군 흡광도).

실험은 3 번 반복 수행하였으며, 결과는 평균값 $\mathrm{SD}$ 로 표시 하였다.

\section{Tyrosinase 저해활성}

Tyrosinase 저해 활성은 김 등의 방법[10]에 따라 실시하였 다. Tyrosinase (100 unit/ml), $60 \mathrm{mM}$ potassium phosphate buffer ( $\mathrm{pH}$ 6.8)와 $0.4 \mathrm{ml}$ 의 $10 \mathrm{mM}$ DOPA (dihydroxyphenylalanine)를 혼합하였다. 혼합용액에 $0.2 \mathrm{ml}$ 의 감태 추 출물을 첨가한 후 $475 \mathrm{~nm}$ 에서 흡광도를 측정하였다. 저해활성 은 다음 방정식으로 계산하였다.

Inhibition $(\%)=\left[\left(\mathrm{A}_{0}-\mathrm{A}_{1}\right) / \mathrm{A}_{0}\right] \times 100$

$\left(\mathrm{A}_{0}=\right.$ 대조군 흡광도, $\mathrm{A}_{1}=$ 실험군 흡광도).

실험은 3 번 반복 수행하였으며, 결과는 평균값 $\pm \mathrm{SD}$ 로 표시 하였다.

\section{통계분석}

통계분석은 SPSS 통계 소프트웨어를 사용하여 수행하였다. 데이터의 normality와 homogeneity는 ANOVA로 확인하였 고, 실험구 간의 차이는 one-way ANOVA와 Duncan"s multiple range test로 평가하였다.

\section{결 과}

\section{페놀성 화합물 함량}

동결건조한 감태 분말로부터 초음파, 물 $\left(65^{\circ} \mathrm{C}\right.$ 및 $\left.24^{\circ} \mathrm{C}\right)$ 및 에탄올 $(50 \%$ 및 $100 \%)$ 추출법을 이용하여 추출물을 제조하고, 추출물의 페놀성 화합물 함량, $\mathrm{DPPH}$ 라디칼 소거 활성 및 tyrosinase 저해 활성을 비교 분석하였다. 페놀성 화합물 함량 은 gallic acid의 표준적정 곡선에 기초하여 감태 건중량 $\mathrm{g}$ 당 $\mathrm{mg}$ 으로 표시하였다. 열수 $\left(65^{\circ} \mathrm{C}\right)$, 물 $\left(24^{\circ} \mathrm{C}\right), 50 \%$ 에탄올 및 $100 \%$ 에탄올을 용매로 추출한 감태 분말의 페놀성 화합물의 함량은 각각 $10.03,6.89,4.23$ 및 $3.01 \mathrm{mg} / \mathrm{g}$ 이었으나, 초음파 기기를 이용한 감태 추출물에서는 $142.80 \mathrm{mg} / \mathrm{g}$ 의 페놀성 화 합물이 추출되었다(Fig. 1). 즉, 초음파 추출이 열수추출에 비 해 약 14 배 이상의 페놀성 화합물의 함량 증진 효과를 나타내 었다 $(p<0.05)$

\section{$\mathrm{DPPH}$ 라디칼 소거활성}

감태 추출물의 항산화 활성 분석을 위하여 $\mathrm{DPPH}$ 라디칼 소거활성법을 적용하였다. 분석결과(Fig. 2) 초음파 추출법에 의한 감태 추출물의 항산화 활성 $(84.73 \%)$ 은 열수 추출법에 의 한 항산화 활성(22.17\%)보다 약 4 배 정도 높게 나타났다 


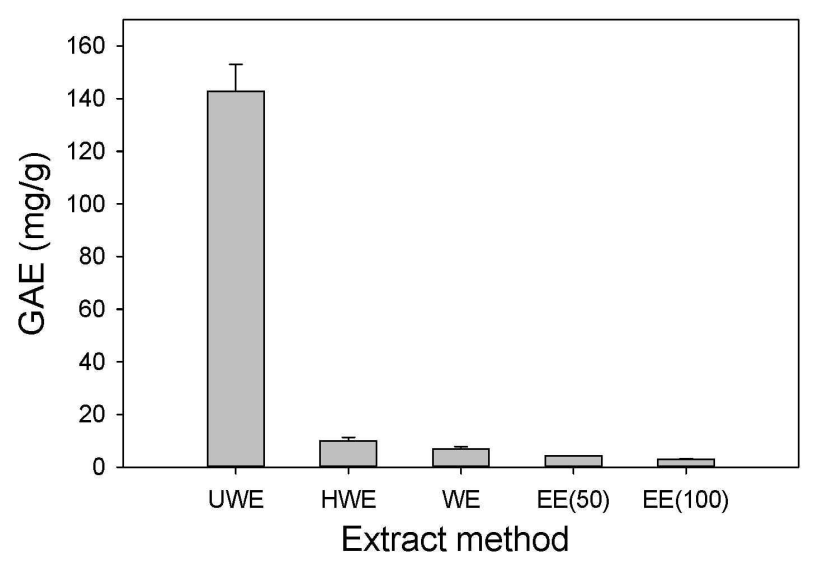

Fig. 1. Total phenolic contents of E. cava extracts by various extraction methods. Results are mean $\pm \mathrm{SD}$ of three parallel measurements. UWE, ultrasonic wave extract; HWE, hot-water extract; $\mathrm{WE}$, water extract; $\mathrm{EE}(50), 50 \%$ ethanol extract; $\mathrm{EE}(100), 100 \%$ ethanol extract.

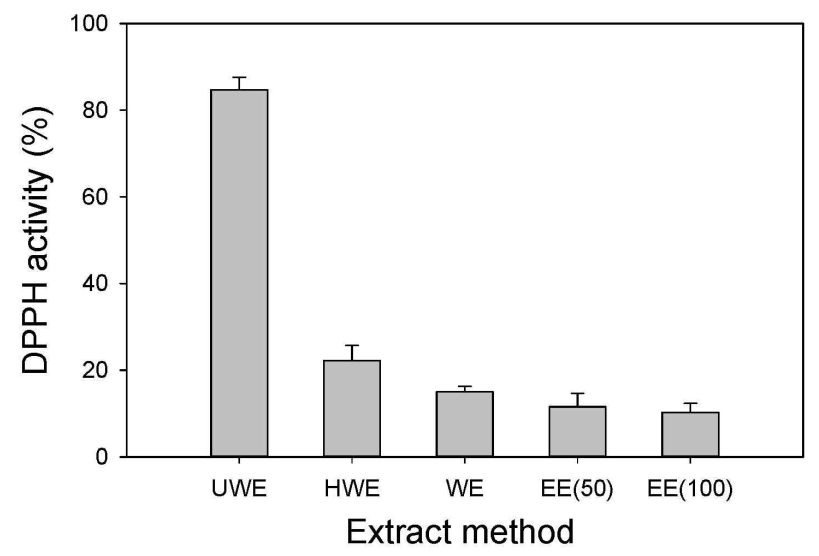

Fig. 2. DPPH radical-scavenging activities of $E$. cava extracts by various extraction methods. Results are mean \pm SD of three parallel measurements. UWE, ultrasonic wave extract; HWE, hot-water extract; WE, water extract; $\mathrm{EE}(50)$, $50 \%$ ethanol extract; $\mathrm{EE}(100), 100 \%$ ethanol extract.

$(p<0.05)$

\section{Tyrosinase 저해 활성}

해조류 추출물의 미백활성을 측정하기 위하여 tyrosinase 저해 활성 측정법을 사용하였다. 분석 결과 초음파 추출법과 열수 추출법에 의한 감태 추출물의 tyrosinase 저해 활성은 각각 $25.95 \%$ 및 $1.87 \%$ 로 분석되어(Fig. 3), 초음파 추출법에 의한 감태 추출물에서 열수 추출법에 의한 추출물보다 tyrosinase 저해 활성이 약 14 배 정도 높았다( $p<0.05)$.

\section{상관관계 분석}

초음파를 비롯한 다양한 추출법에 의한 감태 추출물의 페놀 성 화합물과 항산화 활성 및 tyrosinase 저해 활성간의 상관관

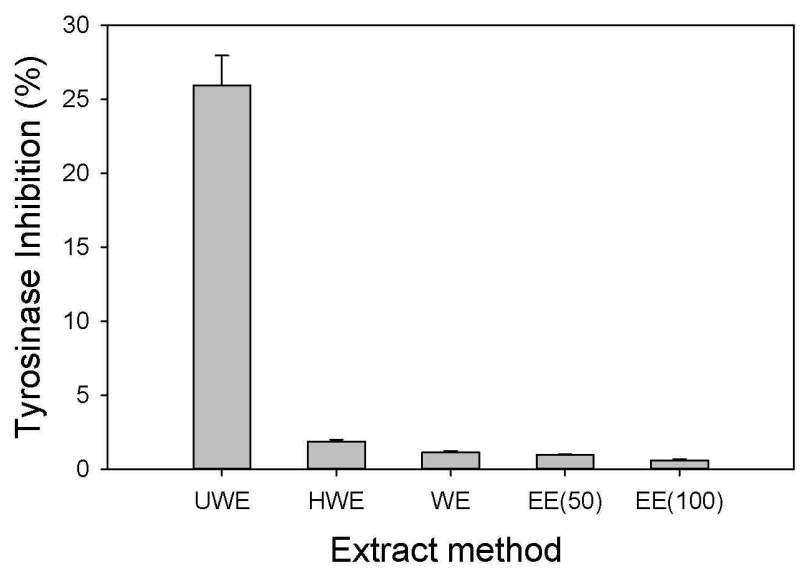

Fig. 3. Tyrosinase inhibitory activities of $E$. cava extracts by various extraction methods. Results are mean \pm SD of three parallel measurements. UWE, ultrasonic wave extract; HWE, hot-water extract; WE, water extract; $\mathrm{EE}(50)$, 50\% ethanol extract; $\mathrm{EE}(100), 100 \%$ ethanol extract.

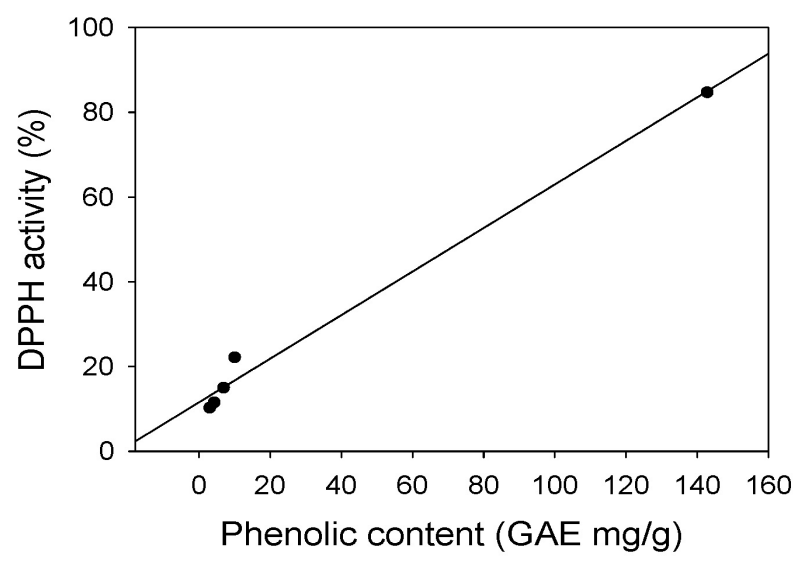

Fig. 4. Correlation between phenolic content and DPPH radical scavenging activity of $E$. cava extracts by various extraction methods.

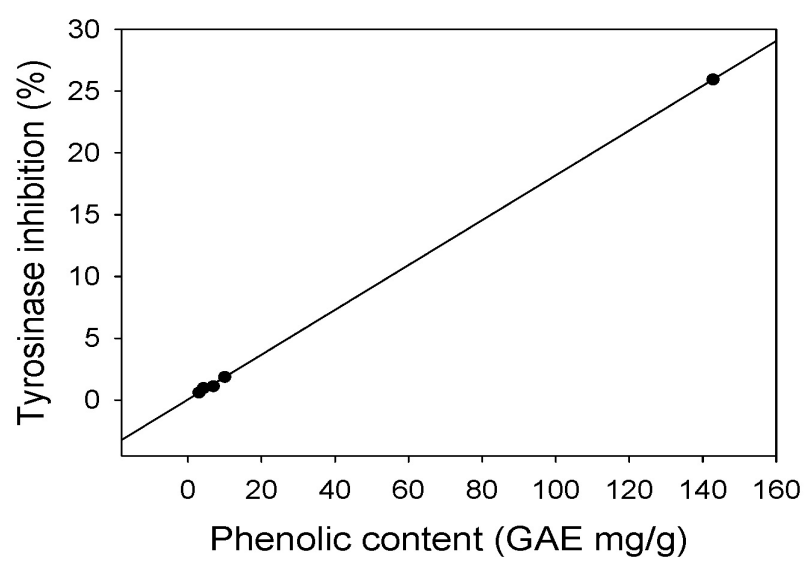

Fig. 5. Correlation between phenolic content and tyrosinase inhibitory activity of $E$. cava extracts by various extraction methods. 
계를 분석하였다(Fig. 1, 2). 다양한 추출방법에 따른 감태 추출 물의 페놀성 화합물 함량과 DPPH 라디칼 소거 활성간의 상관 관계 값은 $\mathrm{R} 2=99.47(\mathrm{Y}=0.5139 \mathrm{X}+11.5872)$, 페놀성 화합물과 tyrosinase 저해 활성간의 상관관계 값은 $\mathrm{R} 2=99.99(\mathrm{Y}=0.1813+$ 0.0506)으로 상관관계가 매우 높게 나타났다(Fig. 4, 5). 이러한 결과는 감태 추출물의 페놀성 화합물 함량과 항산화 활성 및 미백효과 활성간에 강한 연관관계가 있음을 보여주는 것이며, 페놀성 화합물이 감태의 항산화 활성 및 미백활성에 중요한 역할을 담당하고 있음을 나타낸다.

\section{고 찰}

초음파는 $20 \mathrm{kHz}$ 이상의 높은 주파수의 음파로서, 초음파 가 용매를 통과함에 따라 발생하는 공동현상(cavitation)으로 인하여 매우 높은 에너지가 발생하게 된다. 높은 에너지의 충 격으로 인하여 고압이 발생하게 되고, 발생된 높은 압력은 세 포벽 및 세포 내부구조를 쉽게 파열시킨다. 또한 초음파의 기 계적 효과로 인하여 용매가 세포로 침투하게 되어, 초음파 추 출은 식물의 추출 효율을 증가시킨다[21, 22]. 초음파 추출은 전통적인 추출법에 비해 열로 인한 유용성분의 파괴 및 가용 성분 위주의 추출 등을 방지할 뿐만 아니라 추출 시간을 단축 하고, 높은 추출 수율과 생리활성 효과를 기대할 수 있는 추출 방법이다 $[7,22]$. 초음파를 이용한 추출효율 증진보고에 의하 면, 아마란스유와 키틴의 추출시간 단축 $[2,16]$, 향기성분의 추 출효율 증진[26], 색소 추출량 증가[12], 항암활성[22] 및 생체 방어기능 증진[8] 등 다양한 연구가 수행되고 있다.

이 연구에서는 전통적인 열수 및 에탄올을 이용한 추출법 외에 해조류 추출을 위한 초음파 추출법의 적용성을 검토하였 다. 열수추출 $\left(65^{\circ} \mathrm{C}\right)$, 물추출 $\left(24^{\circ} \mathrm{C}\right), 50 \%$ 에탄올 추출 및 $100 \%$ 에탄올 추출 뿐만 아니라 초음파 추출을 수행하여 추출물의 페놀성 화합물 함량, DPPH 라디칼 소거 활성 및 tyrosinase 저해 활성을 분석하고, 초음파 추출과 전통적인 추출법의 차 이를 비교하였다. 감태추출물의 항산화 활성 및 미백활성을 분석하기 위하여 DPPH 라디칼 소거활성 및 tyrosinase 저해 활성법을 적용하였다. DPPH 라디칼 소거 활성은 항산화제가 안정한 자유라디칼인 $\mathrm{DPPH}$ 와 반응하면 $\mathrm{DPPH}$ 를 $\mathrm{DPPHH}$ 로 환원시키고, 흡광도를 감소시키는 원리를 이용하는, 가장 널 리 사용되는 항산화활성 측정법이다[20]. Tyrosinase 저해 활 성은 항산화제 존재하에서 L-lysine 또는 L-DOPA로부터 형성 된 dopachrome을 $475 \mathrm{~nm}$ 에서 측정하는 방법이다[7].

초음파 추출에 의한 감태 추출물의 페놀성 화합물의 함량은 열수 추출물의 약 14 배 이상 높았고(Fig. 1), DPPH 라디칼 소 거 활성은 약 4 배(Fig. 2), tyrosinase 저해 활성은 약 14 배 이상 (Fig. 3) 높은 것으로 나타났다. 특히 열수 추출물에 비해 초음 파 추출물의 페놀성 화합물 함량이 크게 증가된 결과는 carbohydrase, protease 및 메탄올을 이용한 감태 잎 추출물에서
각각 평균 $18.98 \mathrm{mg} / \mathrm{g}, 1953 \mathrm{mg} / \mathrm{g}$ 및 $35.45 \mathrm{mg} / \mathrm{g}$ 의 페놀성 화합물 함량을 보고한 연구[18]와 비교하였을 때, 추출물의 페 놀성 화합물 함량 $(142.80 \mathrm{mg} / \mathrm{g})$ 이 매우 높은 것으로 나타닜 다. 또한 거제 및 제주에서 채집한 30 종의 해조류의 페놀성화 합물을 분석하였을 때 감태의 $50 \%$ 에탄올 추출물에서 가장 높은 페놀성 화합물 함량 $(2.27 \mathrm{mg} / \mathrm{g})$ 이 보고된 바 있는데[11], 이 연구에서의 $50 \%$ 에탄올 추출물의 페놀성 화합물 함량은 $4.23 \mathrm{mg} / \mathrm{g}$ 로 크게 차이나지 않음에도 불구하고, 초음파 추출 법을 사용하였을 때는 페놀성 화합물의 함량이 크게 증가하였 다(Fig. 1). 상관관계 분석 결과, 초음파 추출법에 의한 추출물 에서의 페놀성 화합물 함량과 DPPH 라디칼 소거활성 및 페놀 성 화합물 함량과 tyrosinase 저해 활성간의 상관관계가 $\mathrm{R}^{2}=90$ 이상인 것으로 나타났다(Fig. 4, 5). 이러한 결과는 전통적인 용매 추출법보다 초음파 추출법이 감태의 유용성분 추출에 더 적합함을 의미하며, 초음파 추출법에 의한 감태 추출물은 천연 항산화제 및 향장산업의 원료로 활용가능성이 매우 크다 는 것을 의미한다.

\section{감사의 글}

본 연구는 한국해양과학기술원(과제번호: PE99161) 및 해 양수산부(과제번호: PM57270)의 연구사업의 지원에 의해 이 루어진 것임.

\section{References}

1. Cha, S. H., Ahn, G. N., Heo, S. J., Kim, K. N., Lee, K. W., Song, C. B., Cho, S. K. and Jeon, Y. J. 2006. Screening of extracts from marine green and brown algae in Jeju for potential marine angiotensin- 1 converting enzyme (ACE) inhibitory activity. J Korean Soc Food Sci Nutr 35, 307-317.

2. Chung, K. W., Kim, W. I., Hong, I. K. and Park, K. A. 2000. Ultrasonic energy effects on squalene extraction from amaranth seed. Appl Chem 4, 149-152.

3. Cushnie, T. T. P. and Lamb, A. J. 2005. Antimicrobial activity of flavonoids. Int J Antimicrob Agents 26, 343-356.

4. Devi, G. K., Manivannan, K., Thirumaran, G., Rajathi, F. A. A. and Anantharaman, P. 2011. In vitro antioxidant activities of selected seaweeds from Southeast coast of India. Asian Pac J Trop Med 4, 205-211.

5. Fujimura, T., Tsukahara, K., Moriwaki, S., Kitahara, T., Sano, T. and Takema, Y. 2002. Treatment of human skin with an extract of Fucus vesiculosus changes its thickness and mechanical properties. J Cosmet Sci 53, 1-9.

6. Ibañez, E., Herrero, M., Mendiola, J. A. and Castro-Puyana, M. 2012. Extraction and characterization of bioactive compounds with health benefits from marine resources: Macro and micro algae, cyanobacteria, and invertebrates. pp. 55-98. In: M. Hayes (ed.), Marine bioactive compounds: sources, characterization and applications. Springer Science+Business 
Media

7. Kim, D. H., Kim, H. J. and Chung, B. W. 2006. Extraction of anti-oxidative substance from Haematococcus pluvialis using ultrasonification. J Eng Res 37, 79-86.

8. Kim, J. H., Kim, D. H., You, J. H., Kim, C. H., Kwon, M. C., Seong, N. S., Lee, S. E. and Lee, H. Y. 2005. Immune-regulatory activities of various fractions from Ehpedrae Sinica Stapf, Rubus Coreanus Miq. and Angelica gigas Nakai extracts with ultrasonification. Korean J Med Crop Sci 13, 161-170.

9. Kim, J. K., Cha, W. S., Park, J. H. and Oh, S. L. 1997. Inhibition effect against tyrosinase of condensed tannins from Korea green tea. Korean J Food Sci Technol 29, 173-177.

10. Kim, K. N., Lee, K. W., Song, C. B. and Jeon, Y. J. 2006. Cytotoxic activities of green and brown seaweeds collected from Jeju island against four tumor cell lines. J Food Sci Nutr $11,17-24$.

11. Kim, S., Woo, S., Yun, H., Yum, S., Choi, E., Do, J.-R., Jo, J.-H., Kim, D., Lee, S. and Lee, T.-K. 2005. Total Phenolic Contents and Biological Activities of Korean Seaweed Extracts. Food Sci Biotechnol 14, 798-802.

12. Kim, Y. S. and Choi, J. M. 2007. Effect of ultrasonic treatment on colorants extraction dyeability of safflower. $J$ Korean Home Econ Assoc 45, 13-20.

13. Knorr, D., Zenker, M., Heinz, V. and Lee, D. U. 2004. Application and potential of ultrasonics in food processing. Trends Food Sci Technol 15, 261-266.

14. Kumar, C. S., Ganesan, P., Suresh, P. V. and Bhaskar, N. 2008. Seaweeds as a source of nutritionally beneficial compounds-a review. J Food Sci Technol 45, 1-13.

15. Kumar, M., Gupta, V., Kumari, P., Reddy, C. R. K. and Jha, B. 2011. Assessment of nutrient composition and antioxidant potential of Caulerpaceae seaweeds. J Food Comp Anal 24, 270-278.

16. Kwon, K. N., Choi, H. S. and Cha, B. S. 2009. Effects of microwave and ultrasonication on chitin extraction time. Korean J Food Nutr 22, 8-13.

17. Lee, K. J. and Row, K. H. 2006. Enhanced extraction of isoflavones from Korean soybean by ultrasonic wave. Korean $J$ Chem Eng 23, 779-783.

18. Lee, S. H., Kim, K. N., Cha, S. H., Ahn, G. N. and Jeon,
Y. J. 2006. Comparison of antioxidant activities of enzymatic and methanolic extracts from Ecklonia cava stem and leave. J Korean Sci Food Sci Nutr 35, 1139-1146.

19. Lu, Y. and Foo, L. Y. 2000. Antioxidant and radical scavenging activities of polyphenols apple pomace. Food Chem 68, 81-85.

20. Meenakshi, S., Umayaparvathi, S., Arumugam, M. and Balasubramanian, T. 2012. In vitro antioxidant properties and FTIR analysis of two seaweeds of Gulf of Mannar. Asian Pac J Trop Med S66-S70.

21. Paniwnyk, L., Beaufoy, E., Lorimer, J. P. and Mason, T. J. 2001. The extraction of rutin from flower buds of Sophora japonica. Ultrason Sonochem 8, 299-301.

22. Park, J. H., Lee, H. S., Mun, H. C., Kim, D. H., Seong, N. S., Jung, H. G., Bang, J. K. and Lee, H. Y. 2004. Improvement of Anticancer Activation of Ultrasonificated Extracts from Acanthopanax senticosus Harms, Ephedra sinica Stapf, Rubus coreanus Miq. and Artemisia capillaris Thunb. Korean J Med Crop Sci 12, 273-278.

23. Scheuer, P. J. 1990. Bioorganic marine chemistry. pp. 123. Springer Verlag.

24. Singh, N. and Rajini, P. S. 2004. Free radical scavenging activity of an aqueous extract of potato peel. Food Chem 85, 611-616.

25. Woo, J. H., Shin, S. L., Chang, W. D. and Lee, C. H. 2009. Comparison of antioxidant effects by different extraction methods in flowers of Aster scaber, Aster maackii, Coreopsis lanceolata and Coreopsis tinctoria. Korean J Plant Res 22, 381-388.

26. Xia, T., Shi, S. and Wan, X. 2006. Impact of ultrasonic assisted extraction on the chemical and sensory quality of tea infusion. I Food Eng 74, 557-560.

27. Ye, H., Wang, K., Zhou, C., Liu, J. and Zeng, X. 2008. Purification, antitumor and antioxidant activities in vitro of polysaccharides from the brown seaweed Sargassum pallidum Food Chem 111, 428-432.

28. Yu, S. H., Chong, M. S., Kim, H. J. and Lee, K. N. 2007. Studies on the extraction method and polysaccharide of tricholoma matsutake using the supersonic wave and microwave. Korean J Orient Physiol Pathol 21, 1431-1436. 
초록 : 초음파 추출법에 의한 감태 추출물의 페놀성 화합물 함량, DPPH 라디칼 소거 활성 및 tyrosinase 저해 활성 분석

김소정 ${ }^{1} \cdot$ 김동균 $^{2} \cdot$ 박종범 $^{2} \cdot$ 이택견 ${ }^{*}$

( ${ }^{1}$ 경북해양바이오산업연구원, ${ }^{2}$ 신라대학교 생명과학과, ${ }^{3}$ 한국해양과학기술원 남해특성연구부)

해조류 유래 유용성분 추출을 위한 초음파 추출법의 적용성을 검토하였다. 동결건조한 감태 분말로부터 열수 $\left(65^{\circ} \mathrm{C}\right)$, 물 $\left(24^{\circ} \mathrm{C}\right), 50 \%$ 에탄올 및 $100 \%$ 에탄올 뿐만 아니라 초음파 추출을 수행하여, 추출물을 제조하였다. 추출물 의 페놀성 화합물 함량, DPPH 라디칼 소거 활성 및 tyrosinase 저해 활성을 분석하고, 초음파 추출과 전통적인 추출법의 차이를 비교하였다. 초음파 추출에 의한 감태 추출물의 페놀성 화합물의 함량 $(142.80 \mathrm{mg} / \mathrm{g})$ 은 열수 추 출물의 페놀성 화합물 함량 $(10.03 \mathrm{mg} / \mathrm{g})$ 의 약 14 배 이상 높았다. 열수 추출물에 비해 초음파 추출물의 DPPH 라디칼 소거 활성은 약 4 배, tyrosinase 저해 활성은 약 14 배 이상 높은 것으로 나타났다. 특히 초음파 추출법에 의한 추출물에서의 페놀성 화합물 함량과 DPPH 라디칼 소거활성 및 페놀성 화합물 함량과 tyrosinase 저해 활성 간의 상관관계가 매우 높은 것(각각 $\mathrm{R}^{2}=99.47$ 및 99.99$)$ 으로 나타났다. 이상의 결과는 전통적인 용매 추출법보다 초음파 추출법이 감태의 유용성분 추출에 더 적합함을 의미한다. 